
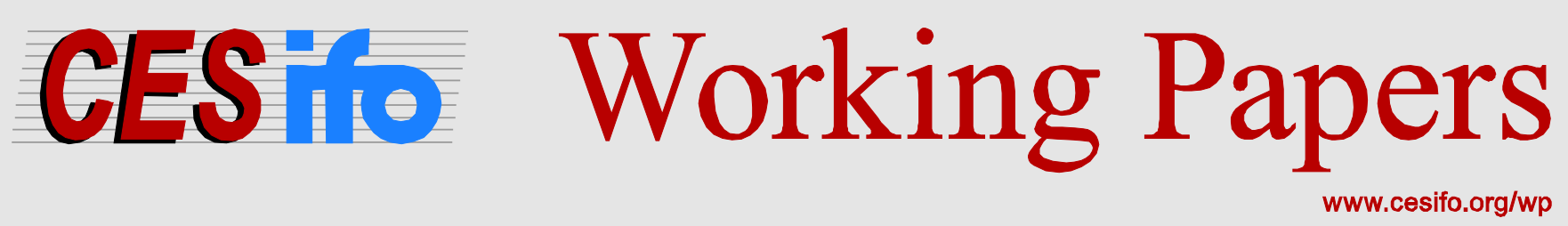

\title{
Business Owners and Income-Shifting between Tax Bases: \\ Empirical Evidence from a Finnish Tax Reform
}

\author{
Jarkko Harju \\ Tuomas Matikka
}

CESIFO WORKING PAPER NO. 5090

CATEGORY 1: Public FinANCE

NOVEMBER 2014

An electronic version of the paper may be downloaded

- from the SSRN website:

- from the RePEc website:

- from the CESifo website:

WwW.SSRN.com

www.RePEc.org

www.CESifo-group.org/wp

\section{CESifo}




\title{
Business Owners and Income-Shifting between Tax Bases: Empirical Evidence from a Finnish Tax Reform
}

\begin{abstract}
This study examines the extent of income-shifting between tax bases among the owners of privately held businesses. The dual income tax system in Finland offers noticeable incentives for income-shifting between wages and dividends for business owners. The dividend tax reform of 2005 enables us to study how this particular form of tax avoidance reacts to an exogenous change in tax rates. Our results support highly active income-shifting behavior. We find that the income-shifting effect is homogeneous across different owners and firms. However, we find that the size of the tax incentive affects the size of the response, indicating that costs related to income-shifting are important.
\end{abstract}

JEL-Code: H240, H250, H320.

Keywords: business owners, income-shifting, income taxation.

Jarkko Harju

Department of Taxation and Social

Transfers /Government Institute for

Economic Research (VATT)

Arkadiankatu 7, P.O.Box 1279

Finland - 00101 Helsinki

jarkko.harju@vatt.fi
Tuomas Matikka

Government Institute for Economic

Research (VATT)

Arkadiankatu 7, P.O.Box 1279

Finland - 00101 Helsinki

tuomas.matikka@vatt.fi 


\section{Introduction}

In many countries business owners and entrepreneurs have a range of opportunities to shift income between tax bases in order to reduce overall tax payments. Therefore, it is important to know how income-shifting incentives affect the extent of this behavior. Income-shifting is generally recognized, but only a few studies offer empirical estimates of its size (Gordon and Slemrod (2000); Devereux et al. (2014); Sivadasan and Slemrod (2008)). Our aim is to provide clear and intuitive evidence on the extent and significance of incomeshifting behavior.

In general, income-shifting is especially relevant for the owners of privately held businesses. Compared to wage earners, business owners have a wider scope of legal possibilities to engage in income-shifting, as they can more easily apply different types of income as a source of personal compensation. ${ }^{1}$ Income-shifting possibilities and tax incentives are pronounced within a so-called dual income tax system (DIT). In a typical DIT, the marginal tax rate schedules for labor income and capital income differ significantly from one another.

In this study we carefully quantify the extent and significance of income-shifting between different tax bases among the owners of privately held corporations in Finland. ${ }^{2}$ In addition, we analyze the heterogeneity of income-shifting among different types of firms and owners. We also study how the size of the incentive affects the income-shifting response.

We exploit the extensive corporate and dividend tax reform of 2005 in Finland as a source of tax rate variation. The reform increased marginal tax rates on dividends by abolishing the single taxation of dividends. Thus the reform increased incentives to pay wages instead of dividends as a form of personal compensation for many business owners. Importantly, income-shifting incentives changed differently among the owners. For some owners there were only small changes in tax rates, whereas some owners faced large changes in income-shifting incentives.

Total tax record data from the Finnish Tax Administration and the opportunity to link tax record information from the owner-level to the firm-level create an interesting starting point to analyze incomeshifting responses. The extensive data allow us to precisely define the tax-optimal composition of total gross income for each owner before and after the reform. Analyzing how changes in the tax-optimal income composition affect the changes in the realized income composition gives us a unique and novel approach to estimate income-shifting responses. Combining this approach with the variation stemming from the tax reform of 2005 offers us credible empirical evidence on the extent of income-shifting behavior.

We find clear support for the view that business owners are active in income-shifting. Tax-optimal income composition has a clear and robust effect on the realized income composition. However, although changes in income-shifting incentives are large, we do not find a one-to-one income-shifting response with respect to tax incentives. This implies that all of the owners do not behave according to a simple tax-minimizing model.

We observe only little heterogeneity in the income-shifting response between different owners or firms.

\footnotetext{
${ }^{1}$ In addition to many tax bases, income-shifting can also occur in other forms. A well-known example is intertemporal income-shifting, for example, in the form of anticipating the forthcoming tax rate change (see for example Goolsbee (2000) and le Maire and Schjerning (2013)). This paper focuses on the longer run effect of income-shifting between tax bases.

${ }^{2}$ Privately held corporations are defined as corporations that are not listed on a public stock exchange. In the Finnish tax system, dividends from listed and privately owned corporations are taxed at different tax rates and tax regulations.
} 
This indicates that income-shifting behavior is not focused on certain types of firms and owners. However, we find that the size of the change in the tax incentive affects the income-shifting responses. This suggests that the costs of income-shifting are important.

Earlier empirical studies concerning income-shifting among business owners have been rather rare. Gordon and Slemrod (2000) offer an overview of the income-shifting literature and show evidence of tax-motivated income-shifting between personal and corporate tax bases among corporate owners in the US. Devereux et al. (2014) also find evidence of active income-shifting between corporate and personal tax bases in the UK. In addition, Sivadasan and Slemrod (2008) find that a decrease in the effective tax rate on wages led to a significant increase in managerial wage compensation for partners of partnership firms in India. In addition, Pirttilä and Selin (2011) show that the relative share of capital income increased among entrepreneurs after the implementation of the Finnish DIT system in 1993. Moreover, concentrated ownership structure is shown to increase tax planning among business owners in the US (Chetty and Saez (2010)).

Within other Nordic Countries, Alstadsæter and Jacob (2012) discuss different tax avoidance channels within the Swedish DIT system, and find evidence of income-shifting between tax bases. Fjaerli and Lund (2001) find support for the hypothesis of active income-shifting among entrepreneurs in Norway. In Denmark, le Maire and Schjerning (2013) provide evidence of income smoothing and intertemporal income-shifting among the self-employed.

The rest of the paper is organized as follows: Section 2 presents the institutional background of the Finnish DIT schedule and describes the main attributes of the 2005 tax reform. Section 3 depicts the theoretical background for our empirical analysis. Section 4 presents the empirical model and descriptive statistics. Section 5 presents the results and Section 6 discusses the main findings.

\section{Finnish dual income tax system and the tax reform of 2005}

Since 1993 Finland has applied the principle of Nordic-type dual income taxation (DIT). In DIT, earned income (wages, pensions, fringe benefits etc.) is taxed at a progressive tax rate schedule, whereas personal capital income (interest income, capital gains, dividends from listed corporations etc.) is taxed at a flat tax rate. A distinctive feature of the DIT system is that the flat tax rate on capital income is set much lower than the highest marginal tax rates on earned income. The lower flat tax rate for capital income was motivated for various reasons, for example, broadening the tax base, decreasing the scope for tax arbitrage, and increased global capital mobility which all argue in favor of taxing capital income more leniently. ${ }^{3}$

Within the DIT system, the wide gap between the marginal tax rates on capital income and earned income creates a tricky task for the legislator: How to formalize the taxation of business owners in such a manner that it prevents income-shifting from heavily taxed earned income to more leniently taxed personal capital income? At the same time, the lawmaker needs to assure that the return on invested capital is not overtaxed.

\footnotetext{
${ }^{3}$ A more detailed discussion on the Nordic type DIT can be found for example in Nielsen and Sørensen (1997) and Sørensen (2005).
} 
In the Finnish system, this issue is arranged by limiting the amount of flat-taxed dividends. Dividends are split into two parts according to the net assets (assets-liabilities) of the firm. The amount of dividends taxed at the capital income tax rate is based on computational normal rate of return on net assets of the firm. This imputed rate of return $(9 \%)$ is set to be the same for all owners of privately held corporations. Dividends less than the computational normal return are flat-taxed, and any dividends exceeding this amount are taxed with the progressive tax rate schedule. ${ }^{4}$

\subsection{The Finnish dual income tax system until 2005}

Until 2005, Finnish DIT applied a full imputation system of corporate taxes to remove the double taxation of dividends, in which dividend income is taxed both as corporate profits and personal income. In the full imputation system, dividends were exempt from corporate taxes. To summarize, taxation of wages and dividends from privately held corporations was organized according to the following rules and principles:

- Dividends:

- Dividends up to the imputed normal return on the net assets of the firm (assets-liabilities) were subject to the flat personal capital income tax rate of $29 \%$.

- Dividends exceeding the imputed normal rate of return were taxed with the progressive tax rate schedule.

- Corporate taxes were fully credited against the dividend tax liability of a shareholder, resulting in single taxation of both flat taxed and progressively taxed dividends.

- Wages were subject to the progressive tax rate schedule (0-56\% in 2002). Wages were single-taxed as they were deductible from firm profits.

- Wages and progressively taxed dividends were not taxed with similar tax rules. Some tax deductions and tax credits were only allowed on wage income. In contrast, progressively taxed dividends were not subject to firm-level social security contributions. ${ }^{5}$

\subsection{The dividend tax reform of 2005}

From 2005 onward, the full imputation system was abolished, and Finland switched to a system with double taxation of dividends. After the reform, dividends are taxed according to the following principles:

\footnotetext{
${ }^{4}$ For example, with net assets of $400,000 \in$, the maximum amount of dividends taxed at the flat tax rate is $36,000 \in \mathbb{E}$ when the imputed return is set to $9 \%(0.09 * 400,000=36,000)$. In other words, any dividends received from the firm below $36,000 \in$ are effectively taxed at the flat tax rate, and any dividends above this amount are subject to progressive taxation with top marginal tax rates above the flat rate. The value of net assets is calculated based on the asset and debt values of the firm in the previous year. The individual net asset share of the owner is calculated based on the ownership share of the firm. Also, there are some individual adjustments to the net assets. For example, if the owner or her family members live in a dwelling which is owned by the firm, the value of this dwelling is not included in net assets when calculating the imputed return.

${ }^{5}$ Firm-level social security contribution rate is $2-6 \%$ of wages, depending on the level of total wages paid and the depreciations made by the firm.
} 
- All dividends became subject to a corporate tax of $26 \%$.

- The splitting rule of dividends according to the imputed rate of return on firm net assets remained unchanged. ${ }^{6}$

- The flat-tax dividends below the imputed return and under 90,000 $€$ remained single-taxed, and are only subject to the flat corporate tax rate of $26 \%$.

- $70 \%$ of all other dividend income is taxable in individual taxation, which results in partial double taxation of dividends.

- Wages and progressively taxed dividends are still taxed differently in terms of social security contributions.

The taxation of dividend income below the amount corresponding to the imputed return on net assets (9\%) did not change significantly in the reform. Effectively, the flat dividend tax rate for dividends below the imputed return and under $90,000 €$ decreased from $29 \%$ to $26 \%$. In general, this means that for owners with large net assets and small dividends, the 2005 tax reform did not induce a notable change in income-shifting incentives.

In contrast, the double taxation rule increased the dividend tax rate for dividends above the imputed return. In general, the abolition of single taxation significantly increased dividend tax rates for owners with low firm net assets. In addition to individual-level progressive taxation, progressively taxed dividends became subject to the flat corporate tax rate of $26 \%$. Thus after the reform, the minimum effective tax rate for progressively taxed dividends is $26 \%$, compared to $0 \%$ before the reform. Furthermore, the flat tax rate increased from $29 \%$ to $40.5 \%$ for flat-tax dividends over $90,000 €$. However, this concerns only a relatively small number of owners.

One important aspect of the reform was its primary motive. According to the European Union Court of Justice, the pre-reform Finnish system of full corporate tax imputation was not in accordance with European Union legislation. Full imputation was granted only to domestic shareholders. Also, the imputed tax credit was not granted to Finnish shareholders whose firms operate abroad. These violated EU regulations on equal tax treatment of all EU citizens. Therefore, Finnish legislators were more or less forced to change the tax system towards a more unified tax treatment. This procedure has important implications for our study. As the reform was not driven by the economic and fiscal conditions in Finland, the tax reform of 2005 can be considered exogenous from the point of view of the owners of privately held corporations.

Finally, the content of the 2005 tax reform was made public already in late 2003. This enabled the owners to anticipate the changes induced by the reform. ${ }^{7}$ Also, special transition rules were applied in 2005 to temporarily alleviate the double taxation of dividends. For these reasons, we focus on analyzing the income-shifting effect by using a longer time period of 2002-2008.

\footnotetext{
${ }^{6}$ However, the imputed rate of return decreased slightly from $9.6 \%$ to $9 \%$.

${ }^{7}$ For evidence of anticipation effects, see Kari et al. (2008).
} 


\subsection{Tax incentives for income-shifting}

There are many possibilities for tax avoidance within the Finnish DIT system. For example, the owners of privately held corporations may seek to minimize taxes by dynamically optimizing the level of net assets, and in a static year-to-year context, by choosing an optimal combination of wages and dividends as their personal compensation from the firm. In this paper we focus on the latter case. Importantly, there are only a few minor legal limitations on whether income is withdrawn as wages or dividends from a privately held corporation in Finland. ${ }^{8}$

The tax-optimal division of total income between wages and dividends is relatively complex. The dividend tax rate schedule comprises of both flat-tax and progressive regions, which depend on the net assets of the firm. The amount of flat-tax dividends can be simply calculated based on the net assets position of the firm. However, wage taxes depend on the level of progressively taxed dividends, and vice versa. Wages and progressively taxed dividends are part of the same tax base even though they are effectively taxed with different tax rates. This complicates the optimization process. When optimizing the income composition, the owner needs to simultaneously consider both the effect of net assets and wage income on the tax rate of dividends. We discuss this issue in the light of our empirical analysis in Section 4.2.

The dividend tax reform of 2005 changed the income-shifting incentives differently among the owners of privately held corporations. Figure 1 illustrates the changes in income-shifting incentives. The Figure presents the marginal tax rates (MTR) on wages and dividends before (2002) and after (2007) the reform with both zero firm-level net assets and with net assets of 170,000 $€$ (median net assets in the data set). ${ }^{9}$

From Figure 1 we can see that wages and dividends were almost equally taxed before the reform for owners with no firm net assets (upper left graph). Differences in tax rates come from the differences in social security payments and tax deductions between wage and dividend income. Dividend taxes increased significantly for this group after 2005 (upper right graph). The double taxation of dividend income increased the MTR of dividends, making the MTR on dividends higher than the MTR on wages. Thus for the owners with low net assets, the reform induced incentives to shift income from dividends to wages. However, as only $70 \%$ of dividends are taxable in individual taxation after the reform, the difference between marginal tax rates decrease at large income levels.

There were no significant changes in the taxation of flat-tax dividends below 90,000€. Before the reform, dividends were in general taxed more leniently than wages for owners with median-level net assets (lower left graph). The reform of 2005 increased dividend taxes for dividends above the flat-taxed region, which brings the MTR on wages and dividends closer to each other (lower right graph).

\footnotetext{
${ }^{8}$ A corporation cannot distribute dividends more than it holds distributable assets. These include, for example, accumulated profits and non-tied equity. With some firms this might limit the scope for income-shifting. Wages cannot be paid when there is no work contribution to the firm. Otherwise wages may be regarded as a veiled distribution of profits. However, this is a minor issue in our analysis since our sample of corporate owners hold an executive position in the firm, and are thus by default assumed by the tax authorities to work for the firm. In contrast to wages and dividends, other alternatives to withdraw income from the firm are restricted. These include, for example, shareholder loans and share repurchases.

${ }^{9}$ Wage tax rates and progressive dividend tax rates include central government taxes, average municipal taxes, applicable individual social security contributions and all automatic deductions and tax credits on either dividend income or wage income or both. In addition, MTR on wages includes firm-level social security contributions. MTR on dividends includes the corporate taxes paid on dividends after the reform.
} 

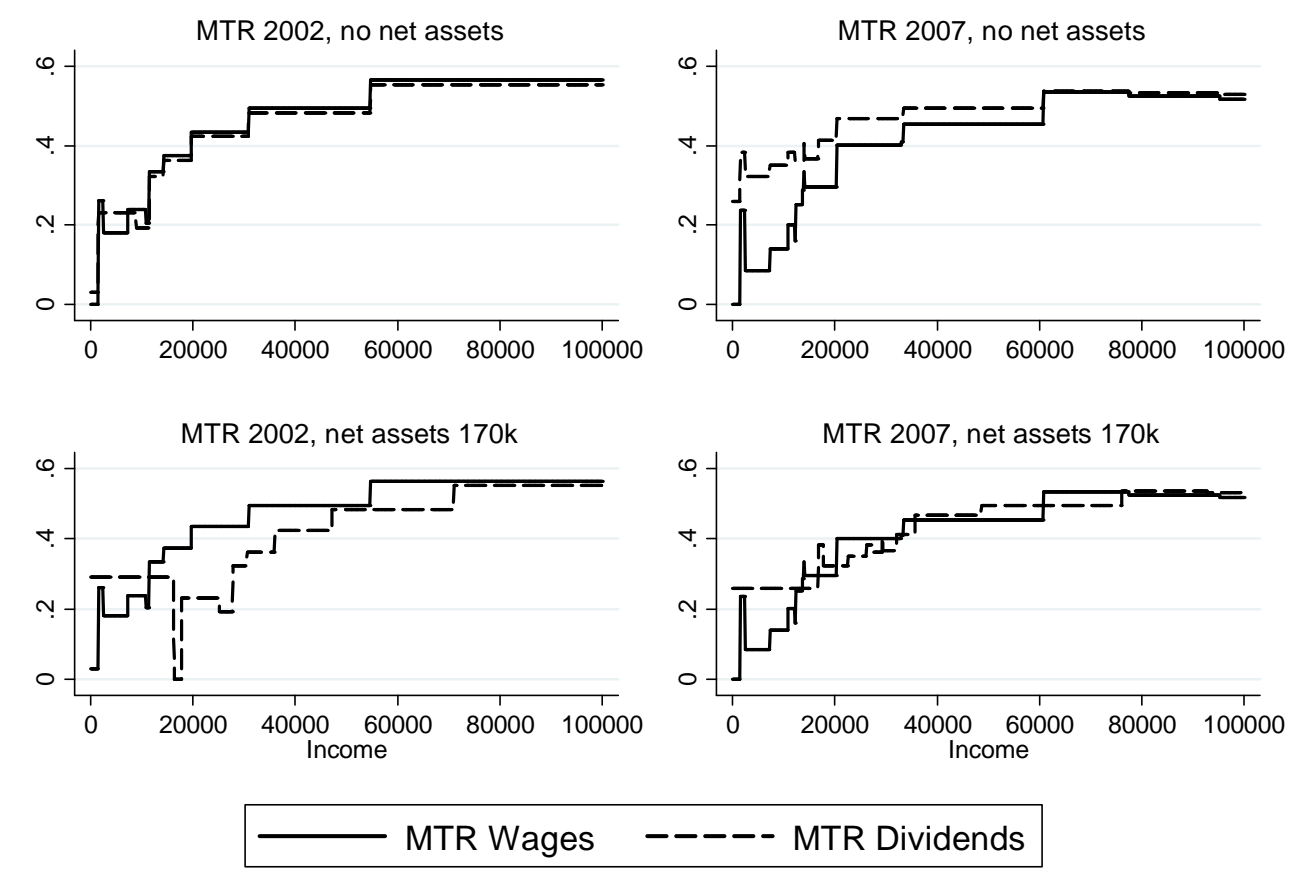

Note: MTR on wages is calculated with dividend income equal to zero and vice versa.

Figure 1: Marginal tax rates (MTR) on wages and dividends: Years 2002 (left) and 2007 (right). Above no net assets, below net assets of $170,000 €$ (in nominal euros each year)

In addition, the reform did not induce significant changes in income-shifting incentives for owners with very large net assets. However, high-income owners with flat-tax dividends above 90,000 $€$ faced a large change in the MTR on dividends (from $29 \%$ to 40.5\%). Table 2 in the Appendix presents the marginal tax rates on wages and dividends in numbers for the years 2002 and 2007 and for firm net assets of $0 €, 170,000$ $€$ and $1,000,000 €$.

Finally, we do not include mandatory pension and health insurance contributions as a tax on wages in this study. Our empirical analysis is limited to owners who own at least $50 \%$ of the firm alone or together with immediate family members, and hold an executive position in the firm. These owners are termed YEL owners in the Finnish tax legislation. YEL owners are subject to special pension insurance rules. YEL owners report a so-called YEL income to the insurance company from which mandatory insurance payments are accumulated from.

Importantly, YEL income does not need to coincide with actual wages paid for the owner. In other words, YEL income can be above or below actual wages paid without implications or sanctions. Thus mandatory insurance contributions have no direct effect on the decision to divide total income into wages and dividends, and are therefore excluded from the income-shifting analysis. ${ }^{10}$

\footnotetext{
${ }^{10}$ There are regulations for both the lower and upper limits of YEL income, which are, however, also independent of actual taxable wage income. Insurance payments determine pensions when retired, as well as the amount of many income-bound social benefits before retirement (e.g. public health insurance). Thus owners have incentives to report a realistic YEL income which reflects the actual income earning potential. There were no relevant changes in contribution rates or other regulation on insurance payments for YEL owners in the time period we study. The overall average rate of insurance payments on YEL income was $21.1 \%$ in 2002 and $20.8 \%$ in 2007.
} 
However, annual wages might be correlated with the reported YEL income. Some owners might report the actual wage income withdrawn from the firm as the YEL income. For these owners, pension and health insurance contributions increase or decrease one-to-one with changes in actual wage income. If insurance contributions are regarded as taxes, this reduces the incentives to pay out more wages. Therefore, insurance contributions might mitigate incentives to pay more wages as a response to increased dividend taxation, which would decrease our income-shifting estimate.

\section{Theoretical framework}

The following model depicts the background for our empirical analysis of tax-motivated income-shifting. In the model, the owner of a privately held corporation both owns a significant part of the corporation and works for the firm. We assume that the owner makes all the relevant decisions about the distribution of profits. Distributed profits are paid out to the owner as a combination of wages and dividends. Wages and dividends are taxed at different tax rate schedules.

The owner receives positive utility from her net-of-tax income (i.e. net wages and net dividends) while costs related to income-shifting reduce utility. The utility function is of the form $U(W+D, \gamma)$, where $W$ is net wages and $D$ is net dividends, and $\gamma$ is the income shifted from wages to dividends. The payout budget constraint is $\Pi-R=W^{g}+D^{g}$, where $\Pi$ is total profits from the firm before taxes, $R$ is retained earnings, and $W^{g}$ and $D^{g}$ are gross wage income and gross dividend income from the firm.

As in Fjaerli and Lund (2001), we focus on the choice of the optimal combination of wages and dividends conditional on given total profits $\Pi$ and retained earnings $R$. In other words, we do not model the incomegenerating process of the firm nor the optimal level of retained and/or distributed profits, and thus simply assume $\Pi$ and $R$ to be exogenous. ${ }^{11}$ We follow this assumption throughout the paper.

More formally, the owner's optimization problem is to

$$
\max U(W+D, \gamma)=\left(1-t_{W}\right)\left(\tilde{W}^{g}-\gamma\right)+\left(1-t_{D}\right)\left(\tilde{D}^{g}+\gamma\right)-\phi(\gamma)
$$

subject to

$$
\Pi-R=W^{g}+D^{g}
$$

In the model, $\tilde{W}^{g}$ and $\tilde{D}^{g}$ represent wage income and dividend income in the absence of income-shifting opportunities. Thus $\left(\tilde{W}^{g}-\gamma\right)=W^{g}$ is the observed gross wage income, and $\left(\tilde{D}^{g}+\gamma\right)=D^{g}$ is the observed gross dividend income. $\phi(\gamma)$ denotes the cost of income-shifting, i.e. the cost of changing the tax base. For simplicity, we assume that $\phi(\gamma)$ is convex, smooth, and $\phi(0)=0$ and $\phi^{\prime}(0)=0$.

\footnotetext{
${ }^{11}$ The choice of retained earnings $(R)$ is relevant in dynamic tax optimization. $R$ increase net assets, which are the base for determining the flat-taxed dividends in the Finnish DIT system. Other than purely tax-motivated issues also define the amount of $R$ (for example, essential investments and imperfect capital markets). In the analysis, we assume that $R$ is already optimized, or simply taken as given. However, the endogenous nature of $R$ does not change the relevance of the static year-toyear tax minimization problem of choosing the tax-optimal combination of wages and dividends. Also, without year-to-year tax optimization, the benefits from dynamic tax avoidance diminish or vanish altogether.
} 
In equation (1), $t_{W}=t_{W}\left(W^{g}, D^{g}, I\right)$ and $t_{D}=t_{D}\left(W^{g}, D^{g}, I\right)$ are the average tax rates on wages and dividends, respectively. Both tax rates are always between zero and one. The tax rate on wage income consists of personal income taxes plus firm-level social security contributions. The tax rate on dividends includes dividend taxes plus corporate taxes associated with withdrawn dividends. Wages are assumed to be deductible from firm profits whereas dividends are not. Also, both tax rates depend on income earned outside the firm, denoted by $I$. This income includes, for example, wages from a secondary job and dividends from other non-listed firms. $I$ is assumed to be exogenous in the model.

Within this general framework, $t_{W}$ is also a function of dividends, and $t_{D}$ is a function of wages. This implies that the amount of wages withdrawn from the firm is allowed to have an effect on the tax rate on dividends, and vice versa. Also, we assume that the tax rate schedules of wages and dividends are "wellbehaved", smooth and monotonically increasing functions of $W^{g}, D^{g}$ and $I$.

We focus on income-shifting responses with given total income. Thus, to simplify the model, we assume that $\tilde{W}^{g}$ and $\tilde{D}^{g}$ are constant. Therefore, we get the optimal income-shifting behavior by taking the first-order condition with respect to $\gamma$, which gives us the following result:

$$
\left(t_{W}+\frac{\partial t_{W}}{\partial \gamma}\right)-\left(t_{D}+\frac{\partial t_{D}}{\partial \gamma}\right)=\phi^{\prime}(\gamma)
$$

Equation (3) says that the combination of gross wages and gross dividends is optimal when the difference between the marginal tax rate on wages $t_{W}+\frac{\partial t_{W}}{\partial \gamma}=M T R_{W}$ and the marginal tax rate on dividends $t_{D}+\frac{\partial t_{D}}{\partial \gamma}=M T R_{D}$ equals the marginal cost of income-shifting.

In our empirical analysis, we relate the change in the observed income combination of wages and dividends $\left(W^{g}, D^{g}\right)$ to the change in the tax-optimal income combination that minimizes tax payments. Our empirical benchmark of tax-minimizing income-shifting behavior refers to the conceptual case where $\phi^{\prime}(\gamma)=0$. With zero income-shifting costs at the margin, the optimality condition is simply

$$
M T R_{W}=M T R_{D}
$$

Equation (4) shows that in order to minimize tax payments, owners adjust $\gamma$ such that the marginal tax rates are equal. This optimality condition determines the combination of gross wages and gross dividends which minimizes taxes. We denote this tax-optimal gross income combination by $\left(W^{*}, D^{*}\right)$.

In addition, our framework provides an intuitive approach to characterize the significance of incomeshifting costs. These costs might be incurred by, for example, the opportunity cost of time or as payments to tax consultants. If owners choose their income compositions such that $M T R_{W}=M T R_{D}$ and thus $\left(W^{g}, D^{g}\right)=\left(W^{*}, D^{*}\right)$, it would indicate both high tax responsiveness of income-shifting as well as low (marginal) costs of income-shifting. Instead, deviations from the tax-optimal condition imply that marginal income-shifting costs are non-negligible, and that these costs affect the decision on the composition of income. Intuitively, this would suggest that income-shifting is more active when tax incentives are larger.

Finally, assumptions behind the theoretical optimality conditions do not generally hold in practice. First, 
real-life marginal tax rate schedules are not smooth and continuous. If anything, the schedules are more or less discontinuous piecewise linear functions of income, which implies, for example, that the actual taxminimizing income combination rarely satisfies the condition $M T R_{W}=M T R_{D}$. Second, optimization errors might occur for at least some owners. ${ }^{12}$ Nevertheless, comparing actual income combinations to the tax-optimal combination $\left(W^{*}, D^{*}\right)$ that minimizes tax payments provides the conceptual background for analyzing the extent and significance of purely tax-motivated income-shifting behavior.

\section{Empirical analysis}

\subsection{Data}

Our data set comes from the Finnish Tax Administration and it includes information on the financial statements and tax records of Finnish businesses and business owners for the years 2002, 2003, 2007 and $2008 .{ }^{13}$ We use it both in a cross-sectional and balanced panel form. The unique characteristic of the data is that they contain basically all Finnish businesses (all public and privately held corporations, partnerships, sole proprietors etc.).

In this study we focus exclusively on the owners of privately held corporations. The data contain all important tax information for the income-shifting analysis, for example taxable wages and dividends paid to the owner by the firm, and income earned from other sources by the owner. By linking the firm-level and the owner-level data together we can analyze the effects of tax changes on owners' income-shifting behavior while consistently controlling for various firm and individual-level effects.

The owner-level data include only those individuals who received positive dividends from the firm during a tax year. Furthermore, we concentrate only on those owners who work in their own firm in an executive position and own at least $50 \%$ of the firm alone or together with immediate family members. We discuss the implications of data and sample restrictions in the end of Section 5.

\subsection{Empirical model}

This section describes the empirical model we use in our analysis. Our aim is to study how the tax-optimal income composition affects the decision to withdraw different types of income from the firm. This relationship can be described with the following cross sectional equation

$$
W_{i, t}^{g}=\beta * W_{i, t}^{*}+X_{i, t}+C_{i}+\alpha_{t}+\varepsilon_{i, t},
$$

\footnotetext{
${ }^{12}$ Also, search costs and other optimization frictions might also matter in optimization behavior (Chetty (2012)). Fjaerli and Lund (2001) suggest that benefits received from paying social security contributions increase wages as a form of compensation, although no compelling evidence has been found to support this view. Also, wages can be seen as a socially more acceptable form of personal compensation. All of these issues imply a deviation from the optimality conditions (3) and (4).

${ }^{13} \mathrm{As}$ mentioned before, the content of the 2005 tax reform was made public already in late 2003. Kari et. al (2008) show evidence that privately held corporations anticipated the reform by increasing dividend payments right before the reform, and decreasing them right afterward. Therefore, we do not use the years closest to the reform in our baseline analysis in order to alleviate the effects caused by anticipation on the longer-run income-shifting response between tax bases.
} 
where $W_{i, t}^{g}$ is realized gross wages from the firm for each owner $i$ in year $t . \quad X_{i, t}$ is a matrix of firm and owner-level variables that affect the amount of gross wage income and the income composition. $C_{i}$ describes time-invariant variables that affect gross wages, such as the innate ability of the owner. ${ }^{14} \alpha_{t}$ is the time trend, and $\varepsilon_{i, t}$ is the error term. Finally, $W_{i, t}^{*}$ is the tax-optimal gross wage with given total income $\Pi_{i, t}-R_{i, t}=$ $W_{i, t}^{g}+D_{i, t}^{g}$. This is the variable of main interest in our analysis. ${ }^{15}$ The parameter $\beta$ denotes the average income-shifting effect on the actual gross wage income withdrawn from the firm.

The tax-optimal gross wage $W_{i, t}^{*}$ summarizes the effects that both the tax rate schedules of wages and dividends have on the actual realized gross wage. As we have the data actually used to tax the owners, we have all the information needed to define the tax-minimizing values $W_{i, t}^{*}$ and $D_{i, t}^{*}$ for every owner each year. The tax-optimal gross wage is calculated using tax register information on the owner's total gross income from the firm $\left(W_{i, t}^{g}+D_{i, t}^{g}\right)$, net assets of the firm, gross earned income from other sources and the tax code and regulations for the year in question. In order to define $\left(W_{i, t}^{*}, D_{i, t}^{*}\right)$ for each owner, we formulate a function that gives the tax-minimizing amount of wages and dividends for each possible total gross income level with respect to every combination of net assets and other earned income. Table 3 in the Appendix presents an illustrative example of the changes in tax optimal gross wages due to the tax reform of 2005 .

As is well known in the microeconometric literature, estimating the causal effect of the tax code on the composition of realized income using equation (5) is difficult in practice. Many of the time-invariant variables that might affect income-shifting behavior are generally unobserved, which violates the exogeneity condition $\operatorname{cov}\left(W_{i, t}^{*}, \varepsilon_{i, t}\right)=0$. Therefore, we use panel data and the tax reform of 2005 to estimate the model. Taking first differences of equation (5) between $t$ and $t+j$ gives us our estimable model

$$
\begin{aligned}
W_{i, t+j}^{g}-W_{i, t}^{g}= & \left(\alpha_{t+j}-\alpha_{t}\right)+\beta *\left(W_{i, t+j}^{*}-W_{i, t}^{*}\right)+ \\
& \left(X_{i, t+j}-X_{i, t}\right)+\left(\varepsilon_{i, t+j}-\varepsilon_{i, t}\right) .
\end{aligned}
$$

In this first-differences (FD) model, the time-invariant component $C_{i}$ gets canceled out by definition. In contrast to the cross sectional one-year analysis in Fjaerli and Lund (2001), we focus on identifying the effect of the tax-optimal income component on the composition of income using exogenous individual variation in $W_{i, t}^{*}$ in time.

Our main interest is in the coefficient $\beta$, which expresses the average effect of a change in tax-optimal gross wages on the change in realized gross wages, conditional on given total gross income in $t$ and $t+j$. The change in the tax-optimal gross wage $W_{i, t+j}^{*}-W_{i, t}^{*}=\Delta W_{i, t}^{*}$ captures all the changes in the individual tax code. In addition to changes in wage taxes, $\triangle W_{i, t}^{*}$ also captures changes in dividend and corporate taxation.

The testable hypotheses in the FD model are the following: If changes in the tax code explain the changes in the composition of income, $\beta$ should be statistically significant and greater than zero. A one-to-one income-

\footnotetext{
${ }^{14}$ In the data, the available controls for $X_{i, t}$ and $C_{i}$ at the owner level are gender, age, other capital income, the ownership share of the firm and location dummies. On the firm level, the controls are turnover, number of employees, profits, total assets, and location and industry dummies.

${ }^{15}$ Fjaerli and Lund (2001) use a similar explanatory variable in their study.
} 
shifting response implies that $\beta=1$. Also, adding control variables to the model should not affect the value of $\beta$, and the coefficients for the controls should not be statistically significant if the change in the tax code is the dominant factor behind the change in the division of income.

\subsection{Identification}

With regard to identifying parameter $\beta$, an important feature is that the tax reform of 2005 changed the income-shifting incentives differently among similar business owners. In other words, $\triangle W_{i, t}^{*}=W_{i, t+j}^{*}-W_{i, t}^{*}$ varies across otherwise similar individuals in the data. Owners with similar total gross income $\left(W_{i, t}^{g}+D_{i, t}^{g}\right)$, other income, ownership share, firm total assets, profits and turnover but with different levels of firm net assets faced different changes in the marginal tax rates on dividends, and thus get different values of $\triangle W_{i, t}^{*}$. Owners with high level of net assets faced only modest changes in their marginal tax rates, whereas owners with low net assets faced larger tax incentives to rearrange their total gross income. Also, different levels of other earned income create variation in tax optimal gross wages, as income earned outside the firm affects the MTR on wages and progressively taxed dividends withdrawn from the firm. We assume that other earned income is exogenous.

A typical strategy in empirical tax research is to use marginal tax rates as explanatory variables when identifying behavioral effects of tax rate changes. However, using $\triangle W_{i, t}^{*}$ as a regressor instead of $\triangle\left(M T R_{W_{i, t}-}\right.$ $M T R_{D_{i, t}}$ ) helps to alleviate the issue of endogenous correlation between the income-shifting incentives and realized gross wages $W_{i, t}^{g}$. The optimal wage $W_{i, t}^{*}$ is not mechanically correlated with $W_{i, t}^{g}$ or $D_{i, t}^{g}$ at a given level of total gross income, whereas marginal or average tax rates themselves are. In most income tax systems, larger wages are associated with higher marginal tax rates and vice versa, causing these variables to be endogenously correlated in a FD model. However, realized gross wages do not affect the value of the taxoptimal gross wage, as $W_{i, t}^{*}$ is the same for any combination of $W_{i, t}^{g}$ and $D_{i, t}^{g}$ at a given level of $\left(W_{i, t}^{g}+D_{i, t}^{g}\right)$. Therefore, in the presence of exogenous tax rate variation, $\triangle W_{i, t}^{*}$ is exogenous in the FD model and does not necessarily require an instrumental variable. In contrast, marginal tax rates would need an instrument, and valid instruments for them are not widely available (see e.g. Saez et al. (2012)).

To identify $\beta$, we need to assume that in the absence of the reform, owners with a large positive $\triangle W_{i, t}^{*}$ do not change their $W_{i, t}^{g}$ differently than owners with smaller changes in $\triangle W_{i, t}^{*}$ (and vice versa). We have no explicit reason to assume that with given total income in $t$ and $t+j$, the change in the realized gross wage $\triangle W_{i, t}^{g}$ depends on other factors than income-shifting incentives, conditional on individual and firm-level covariates. In the model, we control for other individual and firm-level variation in a rich way. In equation (6), $\left(X_{i, t+j}-X_{i, t}\right)$ includes changes in the ownership share and other capital income on the owner's side, and changes in turnover, number of employees, profits and total assets on the firm side.

The empirical approach of using the tax-optimal income component as a measure for income-shifting is not solely linked to Finnish institutions or the dual income tax schedule. This approach generalizes to any case where there are two or more differently taxed tax bases available to the taxpayer. This also applies to different types of income which differ only with respect to tax deductions or allowances. 


\subsection{Descriptive statistics}

One particular advantage of our empirical approach is that we can describe the extent of income-shifting behavior in a visually clear and convincing manner. After defining the tax-optimal combination of gross wages and gross dividends, we can compare the optimal gross wages to realized gross wages. Figure 2 presents the distribution of the difference between the tax-optimal gross wages and realized gross wages for the years 2002 and 2007. Tax-optimal behavior indicates that this difference would be equal to zero. In other words, $W_{i, t}^{g}-W_{i, t}^{*}=0$ if the owner has optimized her wage 'perfectly' with respect to the tax code.

Figure 2 presents the distribution of $W_{i, t}^{g}-W_{i, t}^{*}$ around the tax-optimal point $W_{i, t}^{g}-W_{i, t}^{*}=0$ in the range of $+/-10,000 €$ (in bins of $200 €$ ). The Figure shows that income-shifting behavior is evident. There are clear spikes in the distribution at the level of 0 in both 2002 and 2007. Thus both before and after the reform a notable number of owners withdrew exactly the tax-optimal amount of wage income from the firm. This implies that the tax codes on both wages and dividends affect the total income composition of the owners, as there are no other explicit reasons for the owners to pay out exactly the tax-optimal amount of wages. In relative terms, over $40 \%$ of the owners in our sample optimized their wages perfectly in 2007 . However, in 2002 , we observe less complete wage optimization, as slightly under $15 \%$ of owners optimized their wages.

The monetary gains from income-shifting were smaller before 2005. This means that gains from optimizing the income composition are, on average, larger after the abolition of the single dividend tax system. This might explain the larger spike at the tax-optimal point after the reform in 2007. We further discuss the size of tax incentives and the costs of income-shifting in Section 5. 

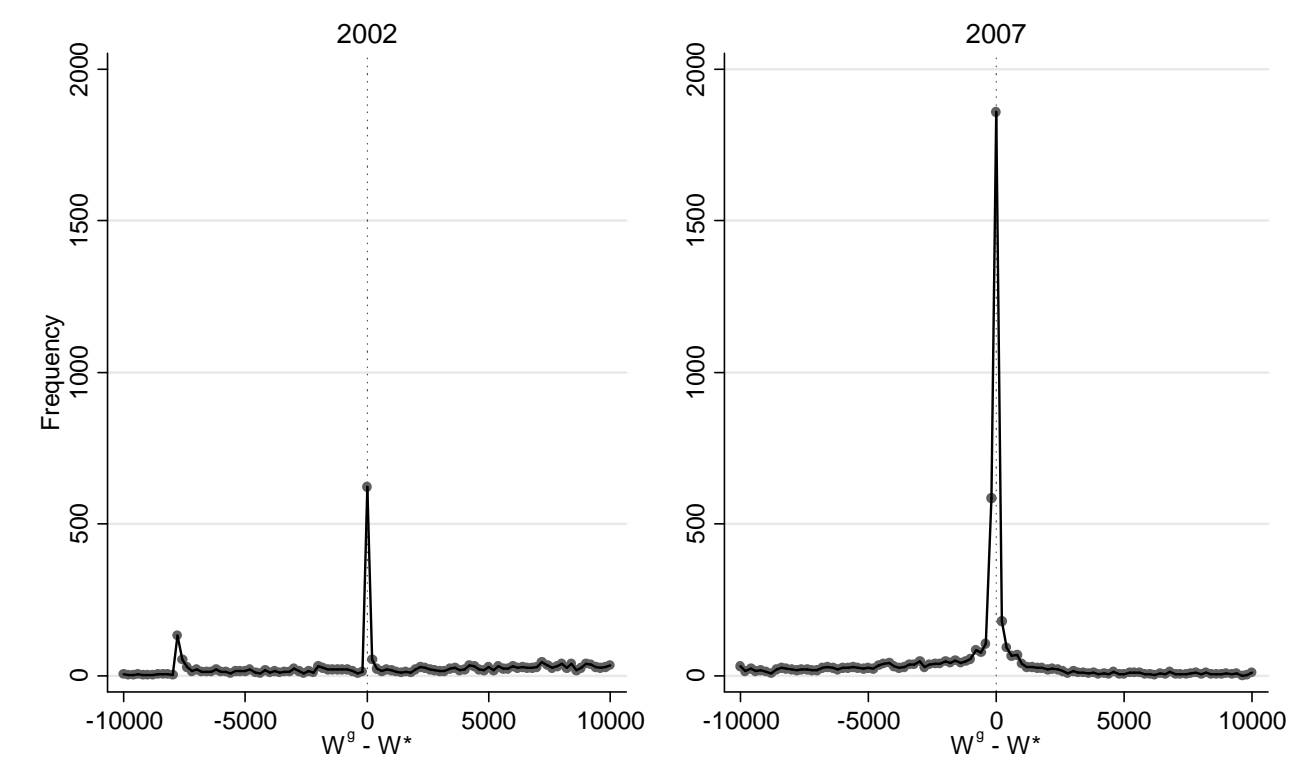

- Number of observations

Bandwidth $=200$ euros

Figure 2: The distribution of the difference between realized gross wages and tax-optimal gross wages in 2002 (left) and 2007 (right)

Figure 3 describes the relationship of the key variables in our study, the change in realized gross wages $\triangle W_{i, t}^{g}=W_{i, t+j}^{g}-W_{i, t}^{g}$ and the change in tax-optimal gross wages $\triangle W_{i, t}^{*}=W_{i, t+j}^{*}-W_{i, t}^{*}$ between the years 2002 and 2007. There is a clear positive relationship between the variables. On average, large $\triangle W_{i, t}^{*}$ are followed by similar $\Delta W_{i, t}^{g}$, which indicates that changes in the realized division of gross income are closely related to the changes in the tax code. Thus the owners who faced large changes in the tax-optimal income composition also changed their realized wages more than the owners who faced no or only small changes in tax incentives.

We fit a non-parametric Kernel estimate with a $95 \%$ confidence interval into Figure 3 to illustrate this effect and its statistical significance. Furthermore, the Figure illustrates that there is a considerable amount of variation in both realized and tax-optimal gross wages in the data. 


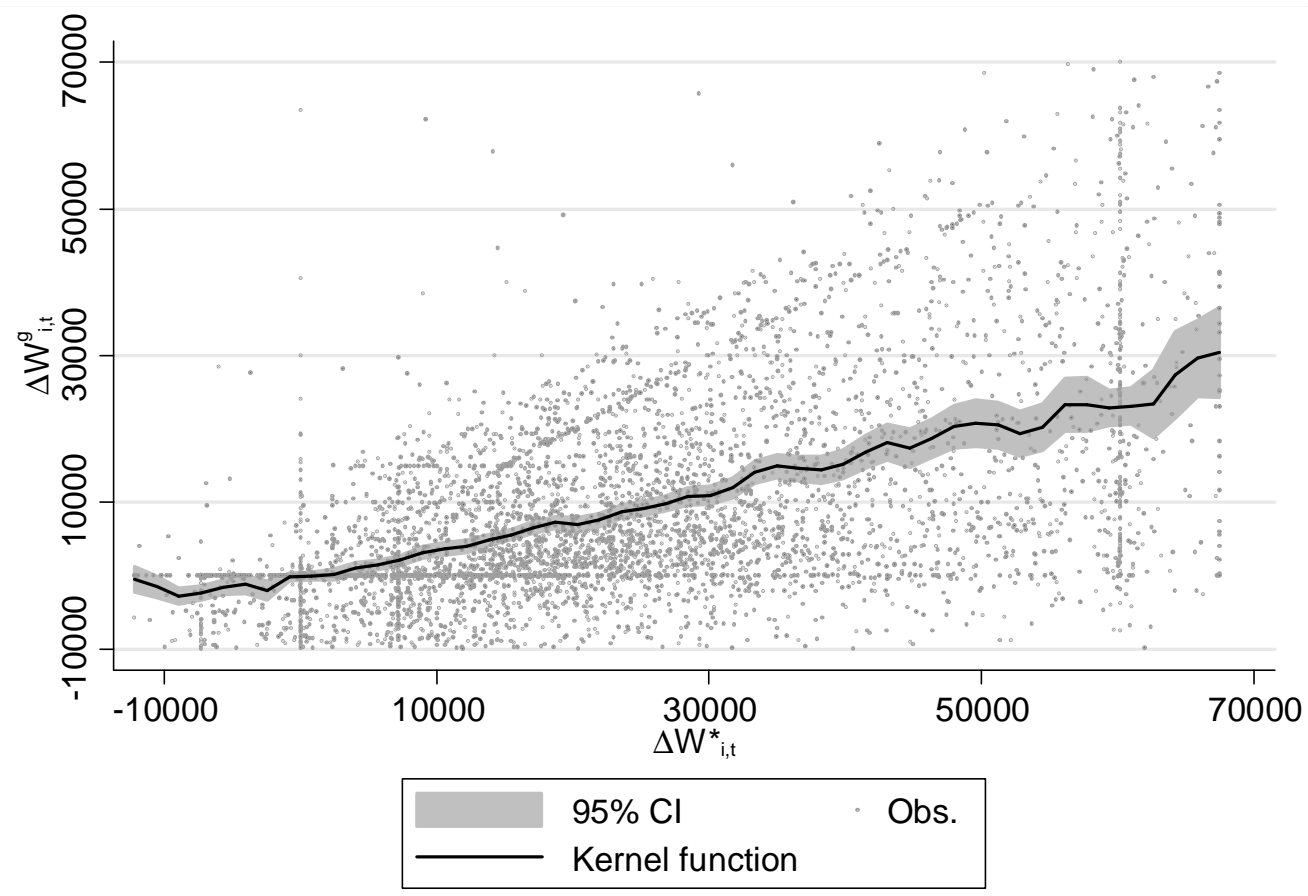

Bandwidth: 1,000 euro

Figure 3: The effect of changes in tax-optimal gross wages $\triangle W_{i, t}^{*}$ on the changes in realized gross wages $\triangle W_{i, t}^{g}$ between 2002 and 2007

Tables 4 and 5 in the Appendix present descriptive statistics for the key variables in our analysis. Table 4 presents the variables at the owner level, and Table 5 describes the characteristics at the firm level. Finally, Figure 5 in the Appendix presents the kernel density estimate distributions of wages and dividends received by the owners of privately held corporations both before (2002) and after (2007) the tax reform of 2005.

\section{Results}

We estimate the first-differences equation (6) using a balanced panel data consisting of the years 2002, 2003, 2007 and 2008, and adding year dummies to the model. We estimate the equation in levels, as many observed and optimal wages and optimal dividends are zeros both before and after the reform. Therefore, for example, a logarithmic model would lose too much information.

The results are presented in Table 1. The first column shows the effect of a change in tax-optimal gross wages on a change in the realized gross wages without control variables. The second column estimates are derived using the full set of individual and firm-level controls. ${ }^{16}$

\footnotetext{
${ }^{16}$ We also estimate the cross sectional model in equation (5) with a full set of control variables. The cross section OLS estimates for the years 2002, 2003, 2007 and 2008 are presented in Table 6 in the Appendix. The results show that the point estimates for the coefficients of tax-optimal gross wages $\left(W^{*}\right)$ are between $0.90-1.05$ and highly significant in every year. These results imply that income-shifting incentives and realized behavior seem to be highly correlated. Fjaerli and Lund (2001) get qualitatively similar results in their cross sectional analysis for Norway.
} 
The owners of privately held corporations react to tax changes very actively. The tax schedule has a remarkable and statistically significant effect on the decision to divide income into wages and dividends. The coefficient for the optimal gross wage implies that a one euro change in the tax-optimal gross wage affects realized gross wages by 66 cents on average. The estimate differs statistically from 1 , so the income-shifting response is not "perfect".

Adding control variables does not change the results. The coefficient for optimal gross wages with controls is very close to the coefficient without them, which supports the view that the tax schedule is the main factor affecting the income composition. Furthermore, adding controls does not affect the fit of the model. The R-squared statistic increases only by 0.01 compared to the model with $\triangle W_{i, t}^{*}$ as the only explanatory variable.

We also use a two-year difference model for the years 2002 and 2008 to estimate the longer-run average effect. These results are presented in Table 7 in the Appendix. When using the data for 2002 and 2008 , the point estimate for income-shifting is approximately 0.68. This estimate is not statistically different from that using the panel data for all four years. This indicates that our results are robust and independent of the length of the difference. ${ }^{17}$

The coefficients of the control variables are mostly insignificant or very small, which again indicates that the changes in the tax system are the driving force behind the decision on income composition. However, the ownership share appears to have a negative effect on realized gross wages. When ownership is concentrated, the owner has more power to make tax optimal decisions on income composition. In this case, increased ownership appears to open up a way to pay out more low-taxed dividends at the expense of wages (given the changes in the tax code). This result is also expected in the light of previous literature. Chetty and Saez (2010) find that tax-optimization is more active among corporate owners who own larger shares of the firm.

In addition, a change in the turnover of the firm has a positive and statistically significant effect on the difference in realized gross wages, although the size of the effect is very small. This can be interpreted as indicating that the growth of the firm (in the sense of turnover) has a small increasing effect on wage compensations, given the change in the tax code. All the other coefficients for firm-level controls are statistically insignificant, including the number of employees, profits and total assets. Therefore, changes in most of the firm-side variables have no significant effect on the division of income on average.

\footnotetext{
${ }^{17}$ The results are robust using all pairs of pre and post-reform years. Other results are available from the authors upon request.
} 


\begin{tabular}{|c|c|c|}
\hline & (1) & $(2)$ \\
\hline VARIABLES & $\Delta$ Wage & $\Delta$ Wage \\
\hline$\Delta W^{*}$ & $\begin{array}{c}0.662^{* * *} \\
(0.007)\end{array}$ & $\begin{array}{c}0.661^{* * *} \\
(0.013)\end{array}$ \\
\hline$\Delta$ Ownership share & & $\begin{array}{c}-71.580^{* *} \\
(33.259)\end{array}$ \\
\hline$\Delta$ Turnover $^{\wedge}$ & & $\begin{array}{c}0.129^{* * *} \\
(0.046)\end{array}$ \\
\hline$\Delta$ Total assets ${ }^{\wedge}$ & & $\begin{array}{c}0.200 \\
(0.206)\end{array}$ \\
\hline$\Delta$ Profits $^{\wedge}$ & & $\begin{array}{c}-0.167 \\
(0.176)\end{array}$ \\
\hline$\Delta$ Employees & & $\begin{array}{c}9.927 \\
(9.469)\end{array}$ \\
\hline$\Delta$ Other capital income ${ }^{\wedge}$ & & $\begin{array}{l}-0.549 \\
(0.382)\end{array}$ \\
\hline Observations & 17,237 & 17,237 \\
\hline R-squared & 0.347 & 0.348 \\
\hline
\end{tabular}

Table 1: Estimation results

Figure 2 in Section 4.4 above gives indicative evidence that supports the hypothesis that costs and benefits matter in income-shifting behavior. The Figure shows that tax-optimal behavior is much more common after the reform of 2005. One explanation for this finding is that income-shifting became more profitable in monetary terms. After the reform, the introduced double taxation of dividends exceeding the imputed return increased the difference of dividend and wage tax rates in many cases, which also increased monetary gains from income-shifting.

In addition, we use a quantile regression approach to illustrate how the size of the incentive affects the response. In Figure 4, we plot the estimates at separate percentile points with the $95 \%$ confidence intervals using equation (6) with the full set of controls. The dashed line in the Figure denotes the average estimate.

As can be seen from the Figure, the point estimates are larger at higher percentiles. At the 95th percentile point, the estimate is not statistically different from 1 . In contrast, the estimates are smaller for those whose tax incentives were not affected as much by the tax reform. Thus it appears that the income-shifting response is positively correlated with the size of the incentive change. 


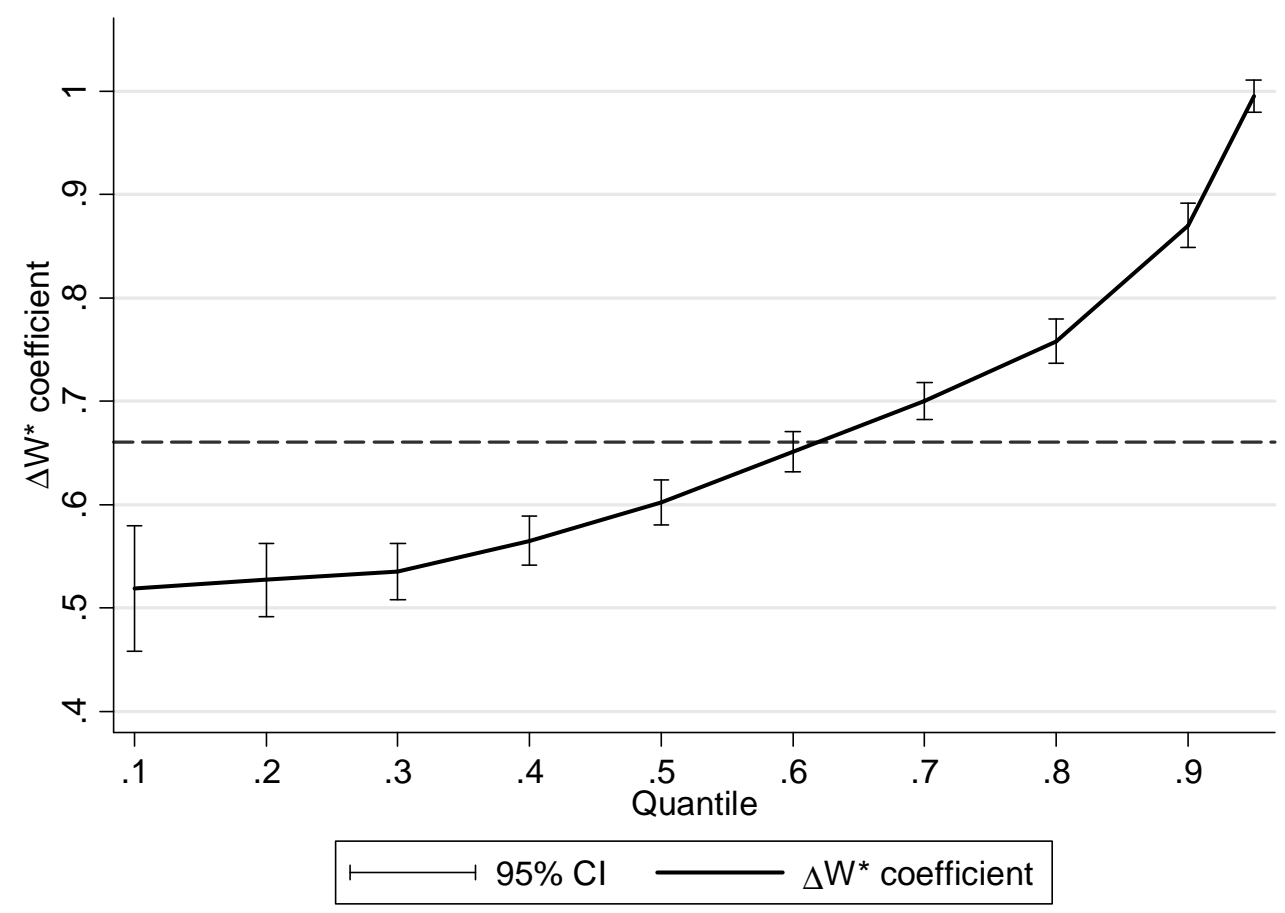

Figure 4: Quantile regression results

To study the heterogeneity of the income-shifting effect, we estimate the model by firm and owner-level characteristics. We categorize firms into four equally sized groups and estimate equation (6) separately for them. We use base-year (2002) turnover, total assets and the number of employees as continuous variables to study if there are differences in income-shifting responses with respect to the size of the firm. We also estimate the model by age and gender of the owner. In addition, we examine if there are differences in income-shifting activity between industries.

The results for different subgroups are presented in Table 8 in the Appendix. In general, the incomeshifting responses are homogeneous between different groups. There are no significant differences incomeshifting activity between women and men, age groups or the size of the firm. Thus these results suggest that the average income-shifting response is not driven by certain types of owners or firms. However, some differences can be detected at the industry level. For example, the owners of firms in financing and agricultural industries shift income more actively than others.

There are some issues regarding the empirical setup that might affect the results. First, our data are limited to owners who receive dividends from their firms in each year. This might bias the estimated average income-shifting effect among Finnish business owners. Also, the direction of the potential bias is somewhat unclear. The owners who do not pay any dividends might be more or less active in tax-motivated incomeshifting compared to the owners who pay dividends. However, it is plausible that the owners not included in the data might be less active in income-shifting, especially before the reform of 2005 when there was in general larger tax incentives to pay dividends. 
Second, our FD analysis uses balanced panel data for a relatively long time period (2002-2008). This implies that our estimating sample includes only owners who were successful enough to continue their business activity throughout this period. It might be that these owners are also more active in income-shifting. Thus this might cause an upward bias in our average estimate.

Third, our sample is limited to owners who own at least $50 \%$ of the firm alone or together with family members. It is presumable that these owners are more responsive to tax incentives than those who own less than $50 \%$. The owners with more than $50 \%$ of the shares of the firm have more power to make tax-optimal decisions on profit distribution.

Finally, as mentioned in Section 2, pension and health insurance contributions might affect the incomeshifting behavior. Insurance contributions are based on self-reported YEL income, which need not to coincide with the actual gross wage income of the owners in our estimating sample. However, wages and YEL income might be correlated among some owners. If insurance contributions are considered as taxes, this might decrease the incentives to increase wage payments as a response to dividend tax increase. This might create a downwards bias to our estimate, as we do not include insurance contributions based on YEL income as taxes when defining the tax-optimal wages.

\section{Discussion}

The main objective of this paper is to provide clear and intuitive evidence on the extent of income-shifting between tax bases among private business owners. We do this by relating the change in the actual income composition of the owner to the change in the tax-optimal income composition. In addition, we explore the heterogeneity of the income-shifting response among different owners and firms, and study how the size of tax incentives affect income-shifting behavior.

In many tax systems, business owners can minimize taxes by choosing an optimal combination of different income types as their personal compensation from the firm. The corporate and dividend tax reform of 2005 in Finland significantly changed the income-shifting incentives for many business owners. In the reform, the taxation of dividends tightened, which increased the incentives to pay wages as a form of personal compensation.

In the light of behavioral tax research, the reform had an appealing feature: the incentives to replace dividends with wages varied among approximately similar corporate owners. This variation in incentives together with extensive micro data, including information on both the owner and firm-level, enable us to credibly analyze the extent of income-shifting behavior.

We find strong and robust evidence that owners are active in income-shifting. Our main result shows that a one euro change in the tax-optimal gross wage results in a 66 cent change in realized gross wages on average. This indicates that the effect of the tax code on the composition of income is significant both statistically and economically. However, our estimate is statistically different from 1 , which implies that not all of the owners behave according to a simple tax-minimizing model. 
The income-shifting response appears to be homogeneous between different firms and owners. For example, the size of the firm does not affect the estimate. This implies that income-shifting behavior is not focused on certain types of firms and owners, and thus it cannot be explained by observable characteristics.

However, our results show that larger income-shifting incentives clearly increase the size of the incomeshifting response. Quantile regression results indicate that responses are larger when incentives to shift income are larger. This (indirectly) implies that the monetary benefits from income-shifting affect the response.

These results point out that a decrease in tax revenue caused by income-shifting can also be influenced by affecting the costs of tax optimization. At least to some extent, the costs and benefits of income-shifting can be affected by simply adjusting the tax regulations, and by decreasing the difference of the marginal tax rates on different tax bases. Finally, it is important to note that our analysis focuses solely on the incomeshifting response. Tax rate changes might also have a significant effect on other behavioral margins, such as investments or entrepreneurial activity. 


\section{References}

[1] Alstadsæter, Annette and Martin Jacob. 2012. Income shifting in Sweden - An empirical evaluation of the 3:12 rules. Report to the Expert Group on Public Economics (ESO) 2012:4, Swedish Ministry of Finance, Stockholm.

[2] Chetty, Raj. 2012. Bounds on elasticities with optimization frictions: A synthesis of micro and macro evidence on labor supply. Econometrica, 80(3): 969-1018.

[3] Chetty, Raj and Emmanuel Saez. 2010. Dividend and corporate taxation in an agency model of the firm. American Economic Journal: Economic Policy, 2(3): 1-31.

[4] Devereux, Michael., Li Liu and Simon Loretz. 2014. The elasticity of corporate taxable income: New evidence from UK tax records. American Economic Journal: Economic Policy, 6(2): 19-53.

[5] Fjaerli, Erik and Diderik Lund. 2001. The choice between owner's wage and dividends under the dual income tax. Finnish Economic Papers, 14: 104-119.

[6] Goolsbee, Austan. 2000. What happens when you tax the rich? Evidence from executive compensation. Journal of Political Economy, 108(2): 352-378.

[7] Gordon, Roger and Joel Slemrod. 2000. Are "real" responses to taxes simply income shifting between corporate and personal tax bases?, in Joel Slemrod (ed.), Does Atlas Shrug? The Economic Consequences of Taxing the Rich, Russell Sage Foundation and Harvard University Press, 2000: pp. 240-280.

[8] Kari, Seppo, Hanna Karikallio and Jukka Pirttilä. 2008. Anticipating tax changes: Evidence from the Finnish corporate income tax reform of 2005. Fiscal Studies 29(2): 167-196.

[9] le Maire, Daniel and Bertel Schjerning. 2013. Tax bunching, income shifting and selfemployment. Journal of Public Economics, 107: 1-18.

[10] Nielsen, Søren Bo and Peter Birch Sørensen. 1997. On the optimality of the Nordic system of dual income taxation. Journal of Public Economics, 63: 311-329.

[11] Pirttilä, Jukka and Håkan Selin. 2011. Income shifting within a dual income tax system. Evidence from the Finnish tax reform of 1993. Scandinavian Journal of Economics, 113(1): 120-144.

[12] Saez, Emmanuel, Joel Slemrod and Seth Giertz. 2012. The elasticity of taxable income with respect to marginal tax rates: A critical review. Journal of Economic Literature, 50(1): 3-50.

[13] Sivadasan, Jagadeesh and Joel Slemrod. 2008. Tax law changes, income-shifting and measured wage inequality: Evidence from India. Journal of Public Economics, 92: 2199-2224.

[14] Sørensen, Peter Birch. 2005. Neutral taxation of shareholder income. International Tax and Public Finance, 12: 777-801. 


\section{Appendix}

\begin{tabular}{|c|c|c|c|c|c|c|c|c|}
\hline \multirow[b]{2}{*}{ Income } & \multicolumn{2}{|c|}{ MTR on wages } & \multicolumn{2}{|c|}{$\begin{array}{c}\text { MTR on } \\
\text { dividends (no } \\
\text { net assets) }\end{array}$} & \multicolumn{2}{|c|}{$\begin{array}{c}\text { MTR on } \\
\text { dividends (net } \\
\text { assets } 170 \mathrm{k} \text { ) }\end{array}$} & \multicolumn{2}{|c|}{$\begin{array}{l}\text { MTR on } \\
\text { dividends (net } \\
\text { assets } 1,000 \mathrm{k} \text { ) }\end{array}$} \\
\hline & 2002 & 2007 & 2002 & 2007 & 2002 & 2007 & 2002 & 2007 \\
\hline 5,000 & 18.1 & 11.6 & 23.1 & 32.3 & 29.0 & 26.0 & 29.0 & 26.0 \\
\hline 10,000 & 23.9 & 17.0 & 19.3 & 35.1 & 29.0 & 26.0 & 29.0 & 26.0 \\
\hline 15,000 & 37.4 & 32.6 & 36.3 & 36.6 & 29.0 & 26.0 & 29.0 & 26.0 \\
\hline 20,000 & 43.4 & 32.6 & 42.3 & 41.3 & 23.1 & 32.3 & 29.0 & 26.0 \\
\hline 25,000 & 43.4 & 43.1 & 42.3 & 46.7 & 23.1 & 35.1 & 29.0 & 26.0 \\
\hline 30,000 & 43.4 & 43.1 & 42.3 & 46.7 & 32.3 & 36.6 & 29.0 & 26.0 \\
\hline 35,000 & 49.4 & 48.5 & 48.3 & 49.5 & 36.3 & 41.3 & 29.0 & 26.0 \\
\hline 40,000 & 49.4 & 48.5 & 48.3 & 49.5 & 42.3 & 46.7 & 29.0 & 26.0 \\
\hline 45,000 & 49.4 & 48.5 & 48.3 & 49.5 & 42.3 & 46.7 & 29.0 & 26.0 \\
\hline 50,000 & 49.4 & 48.5 & 48.3 & 49.5 & 48.3 & 49.5 & 29.0 & 26.0 \\
\hline 55,000 & 56.4 & 48.5 & 55.3 & 49.5 & 48.3 & 49.5 & 29.0 & 26.0 \\
\hline 60,000 & 56.4 & 48.5 & 55.3 & 49.5 & 48.3 & 49.5 & 29.0 & 26.0 \\
\hline 65,000 & 56.4 & 56.5 & 55.3 & 53.7 & 48.3 & 49.5 & 29.0 & 26.0 \\
\hline 70,000 & 56.4 & 56.5 & 55.3 & 53.7 & 48.3 & 49.5 & 29.0 & 26.0 \\
\hline 75,000 & 56.4 & 56.5 & 55.3 & 53.7 & 55.3 & 49.5 & 29.0 & 26.0 \\
\hline 80,000 & 56.4 & 55.6 & 55.3 & 53.2 & 55.3 & 53.7 & 29.0 & 26.0 \\
\hline 85,000 & 56.4 & 55.6 & 55.3 & 53.2 & 55.3 & 53.7 & 29.0 & 26.0 \\
\hline 90,000 & 56.4 & 55.6 & 55.3 & 53.2 & 55.3 & 53.7 & 29.0 & 26.0 \\
\hline 95,000 & 56.4 & 55.6 & 55.3 & 53.2 & 55.3 & 53.2 & 29.0 & 32.3 \\
\hline 100,000 & 56.4 & 54.8 & 55.3 & 52.8 & 55.3 & 53.2 & 23.1 & 35.1 \\
\hline
\end{tabular}

Notes:

MTR on wages is calculated with dividend income equal to zero, and vice versa. MTR on wages includes average municipal taxes, central government income taxes, automatic tax deductions and tax credits and average firm-level social security contributions (3\%). MTR on wages does not include pension and health insurance contributions, as these are based on self-reported YEL income which is not determined by wage income (see Section 2). MTR on wages does not include deductions based on insurance contributions. MTR on dividends includes corporate taxes on withdrawn dividends (after 2005). MTR on dividends includes all automatic tax deductions and tax credits. MTR on progressively taxed dividends includes average municipal taxes and central government income taxes. Marginal tax rates are calculated using Stata and the Finnish JUTTA microsimulation model.

Table 2: Marginal tax rates (MTR) on wages and dividends with different levels of firm net assets, years 2002 and 2007 (in nominal euros) 


\begin{tabular}{|c|c|c|c|c|c|}
\hline $\begin{array}{c}\text { Total } \\
\text { gross } \\
\text { income }\end{array}$ & $\begin{array}{c}\text { Net } \\
\text { assets }\end{array}$ & $\begin{array}{c}\text { Tax optimal } \\
\text { gross wage } \\
\text { 2002 }\end{array}$ & $\begin{array}{c}\text { Tax optimal } \\
\text { gross wage } \\
\text { 2003 }\end{array}$ & $\begin{array}{c}\text { Tax optimal } \\
\text { gross wage } \\
\text { 2007 }\end{array}$ & $\begin{array}{c}\text { Tax optimal } \\
\text { gross wage } \\
2008\end{array}$ \\
\hline 15,000 & 10,000 & 7,700 & 7,300 & 14,500 & 14,100 \\
50,000 & 10,000 & 7,700 & 7,300 & 49,100 & 49,100 \\
100,000 & 10,000 & 7,700 & 7,300 & 67,500 & 66,000 \\
\hline 15,000 & 100,000 & 12,000 & 12,200 & 14,500 & 14,000 \\
50,000 & 100,000 & 7,700 & 7,300 & 41,000 & 41,000 \\
100,000 & 100,000 & 7,700 & 7,300 & 67,500 & 66,000 \\
\hline 15,000 & 500,000 & 12,000 & 12,200 & 14,500 & 14,000 \\
50,000 & 500,000 & 12,000 & 12,200 & 14,500 & 14,000 \\
100,000 & 500,000 & 7,700 & 7,300 & 55,000 & 55,000 \\
\hline
\end{tabular}

The optimal gross wage levels are defined assuming that the owner owns $100 \%$ of the shares and that the owner has no earned income from other sources.

In general, earned income from other sources lowers the tax optimal gross wage, especially before the reform. For example, assume the owner has $2,500 €$ of other earned income with total gross income from the firm being $50,000 €$ and net assets $100,000 €$. The tax optimal gross wage in 2003 is in this case 4,800 (compared to 7,300 $€$ without other earned income). However, with the same combination of total gross income, net assets and other earned income, the optimal gross wage does not change after the reform (41,000 $€$ in both 2007 and 2008). This is due to the fact that after 2005 the tax rates for progressively taxed dividends increased sharply. After the reform, it is not in general optimal for the owner to replace wages with dividends after receiving a modest amount of other earned income.

Table 3: Tax-optimal gross wages before $(2002,2003)$ and after $(2007,2008)$ the 2005 tax reform with different levels of total gross income and net assets of the firm (in nominal euros)

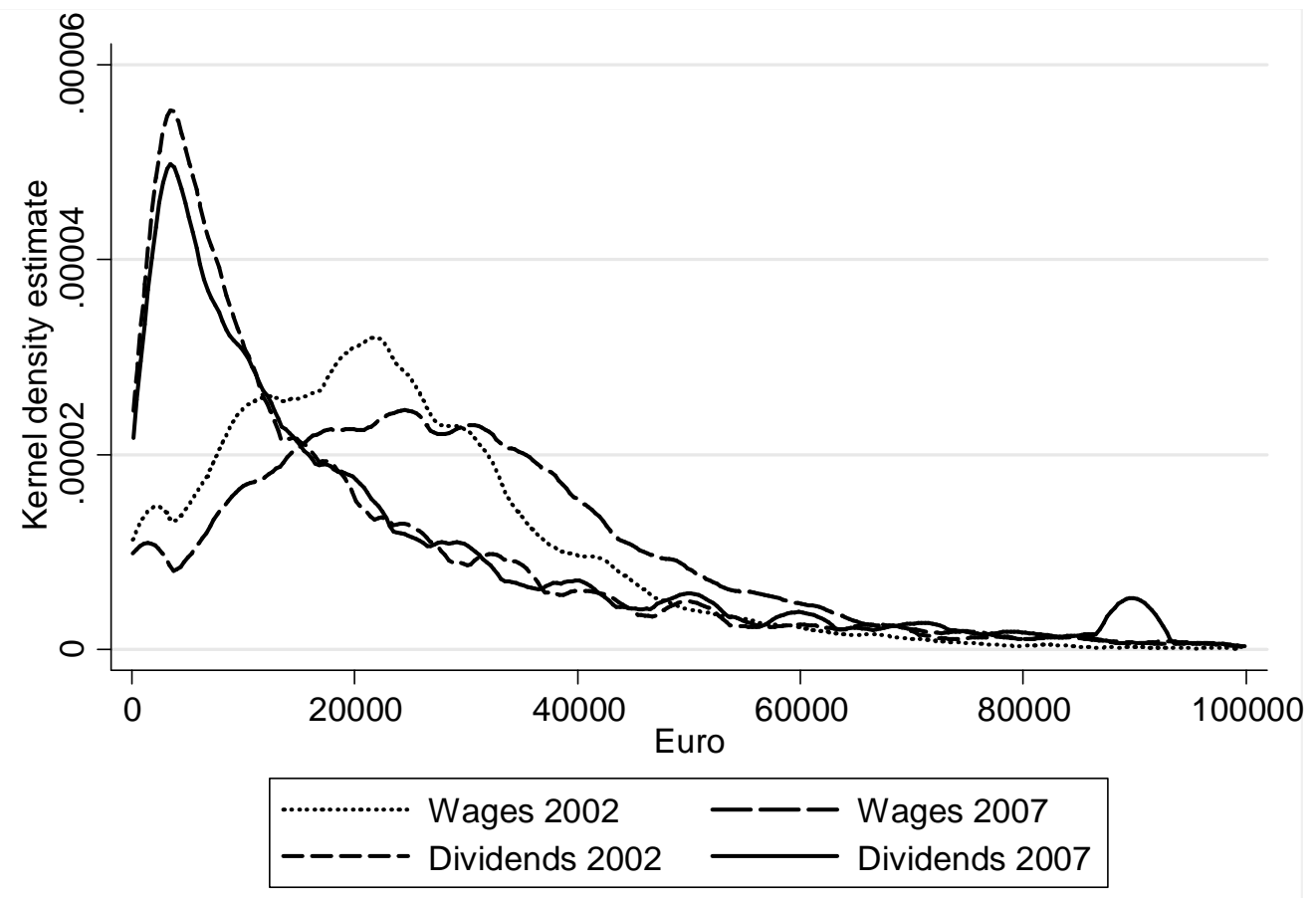

Bandwidth: 1,500 euro

Figure 5: The distributions of wage and dividend income of the owners of privately held corporations in 2002 and 2007 (in nominal euros) 


\begin{tabular}{cccccccc}
\hline \multirow{2}{*}{ Year } & & & Optimal & & \multicolumn{2}{c}{ Optimal } & \multicolumn{2}{c}{ Total } & \multicolumn{2}{c}{ Ownership } \\
\hline \multirow{2}{*}{ Stat } & Wages & wages & Dividends & dividends & income & share \\
& Mean & 19,806 & 5,317 & 27,105 & 41,594 & 46,911 & 0.82 \\
& Median & 18,485 & 7,463 & 12,222 & 28,797 & 34,567 & .93 \\
& SD & 16,986 & 3,499 & 82,510 & 84,965 & 85,066 & 0.23 \\
\hline \multirow{2}{*}{2003} & N & 6,277 & 6,277 & 6,277 & 6,277 & 6,277 & 6,277 \\
& Mean & 19,244 & 4,794 & 32,744 & 47,194 & 51,988 & 0.84 \\
& Median & 17,223 & 7,011 & 15,000 & 31,783 & 36,996 & .95 \\
& SD & 17,318 & 3,401 & 142,723 & 144,477 & 144,533 & 0.23 \\
& N & 6,277 & 6,277 & 6,277 & 6,277 & 6,277 & 6,277 \\
\hline \multirow{2}{*}{2007} & Mean & 23,083 & 26,033 & 32,767 & 29,817 & 55,850 & 0.82 \\
& Median & 20,440 & 23,888 & 14,910 & 11,267 & 40,170 & .99 \\
& SD & 22,443 & 19,416 & 99,552 & 100,123 & 102,931 & 0.22 \\
& N & 6,277 & 6,277 & 6,277 & 6,277 & 6,277 & 6,277 \\
\hline & Mean & 23,980 & 26,233 & 35,487 & 33,234 & 59,468 & 0.82
\end{tabular}

Table 4: Descriptive statistics (2002, 2003, 2007 and 2008): Main owners (baseline estimation sample, in nominal euros)

\begin{tabular}{cccccc}
\hline Year & Stat & Turnover & Employees & $\begin{array}{c}\text { Total } \\
\text { assets }\end{array}$ & Net assets \\
\hline \multirow{2}{*}{2002} & Mean & 782,450 & 10.35 & 400,805 & 285,155 \\
& Median & 227,617 & 4 & 141,598 & 100,222 \\
& SD & $4,092,140$ & 32.98 & $2,174,166$ & $1,669,665$ \\
& N & 6,277 & 6,277 & 6,277 & 6,277 \\
\hline \multirow{2}{*}{2003} & Mean & 946,741 & 10.27 & 529,807 & 381,950 \\
& Median & 289,713 & 4 & 192,240 & 114,693 \\
& SD & $3,982,281$ & 30.64 & $2,375,763$ & $5,233,616$ \\
& N & 6,277 & 6,277 & 6,277 & 6,277 \\
\hline \multirow{2}{*}{2007} & Mean & $1,082,630$ & 10.60 & 723,319 & 448,007 \\
& Median & 321,193 & 4 & 253,792 & 152,155 \\
& SD & $3,155,168$ & 36.14 & $2,985,295$ & $2,378,661$ \\
& N & 6,277 & 6,277 & 6,277 & 6,277 \\
\hline & Mean & $1,152,018$ & 10.63 & 811,968 & 516,807 \\
& Median & 329,951 & 4 & 272,411 & 168,326 \\
& SD & $3,329,805$ & 36.25 & $3,452,935$ & $2,791,899$ \\
& $\mathrm{~N}$ & 6,277 & 6,277 & 6,277 & 6,277 \\
\hline
\end{tabular}

Table 5: Descriptive statistics (2002, 2003, 2007 and 2008): Firms (baseline estimation sample, in nominal euros) 


\begin{tabular}{|c|c|c|c|c|}
\hline & $(2002)$ & $(2003)$ & $(2007)$ & $(2008)$ \\
\hline VARIABLES & Wage & Wage & Wage & Wage \\
\hline \multirow[t]{2}{*}{$W^{*}$} & $1.050 * * *$ & $1.054^{* * *}$ & $0.904^{* * *}$ & $0.920^{* * *}$ \\
\hline & $(0.075)$ & $(0.071)$ & $(0.014)$ & $(0.014)$ \\
\hline \multirow[t]{2}{*}{ age } & $731.402^{* * *}$ & $796.057^{* * *}$ & 152.225 & 12.443 \\
\hline & $(178.766)$ & $(177.301)$ & $(166.080)$ & $(180.034)$ \\
\hline \multirow[t]{2}{*}{ age sq. } & $-8.102^{* * *}$ & $-9.032 * * *$ & -1.295 & 0.112 \\
\hline & $(1.912)$ & $(1.852)$ & $(1.650)$ & $(1.770)$ \\
\hline \multirow[t]{2}{*}{ male } & $2,054.167^{* * *}$ & $1,887.503^{* * *}$ & 222.468 & 84.810 \\
\hline & $(632.076)$ & $(610.805)$ & $(471.941)$ & $(499.349)$ \\
\hline \multirow[t]{2}{*}{ ownership share } & $-5,615.921 * * *$ & $-6,330.395^{* * *}$ & $-3,311.677^{* * *}$ & $-1,922.041 * *$ \\
\hline & $(1,003.374)$ & $(975.413)$ & $(773.002)$ & $(878.509)$ \\
\hline \multirow[t]{2}{*}{ turnover^ } & 0.086 & -0.033 & 0.190 & $0.345^{* *}$ \\
\hline & $(0.153)$ & $(0.260)$ & $(0.127)$ & $(0.167)$ \\
\hline \multirow[t]{2}{*}{ total assets^ } & -0.227 & $0.988^{* *}$ & $0.304^{*}$ & $0.306^{*}$ \\
\hline & $(0.228)$ & $(0.471)$ & $(0.184)$ & $(0.173)$ \\
\hline \multirow[t]{2}{*}{ profits^ } & $8.841 * * *$ & -0.275 & $-0.554^{*}$ & -0.012 \\
\hline & $(2.300)$ & $(3.150)$ & $(0.330)$ & $(0.241)$ \\
\hline \multirow[t]{2}{*}{ employees } & 18.056 & 28.357 & 5.856 & 3.339 \\
\hline & $(23.840)$ & $(25.448)$ & $(5.471)$ & $(7.259)$ \\
\hline \multirow[t]{2}{*}{ capital income^ } & $-1.132 * * *$ & -11.207 & 0.610 & 1.200 \\
\hline & $(0.424)$ & $(9.352)$ & $(1.833)$ & $(2.311)$ \\
\hline \multirow[t]{2}{*}{ Constant } & $-4,342.653$ & $-2,223.960$ & $2,042.214$ & $2,396.998$ \\
\hline & $(4,351.468)$ & $(4,047.587)$ & $(4,210.924)$ & $(4,599.538)$ \\
\hline Observations & 5,160 & 5,611 & 6,244 & 6,237 \\
\hline R-squared & 0.115 & 0.114 & 0.637 & 0.613 \\
\hline
\end{tabular}

Notes: Owner-level clustered robust standard errors in parentheses. ${ }^{* *} \mathrm{p}<0.01,{ }^{* *} \mathrm{p}<0.05,{ }^{*} \mathrm{p}<0.1$.

^ In 1,000 euros

Table 6: Cross-section results for the years 2002, 2003, 2007 and 2008

\begin{tabular}{lcc}
\hline & $(1)$ & $(2)$ \\
VARIABLES & $\Delta \mathrm{W}$ & $\Delta \mathrm{W}$ \\
\hline$\Delta W^{*}$ & $0.681^{* * *}$ & $0.680^{* * *}$ \\
& $(0.012)$ & $(0.016)$ \\
$\Delta$ Ownership share $^{*}$ & -9.120 \\
& & $(52.054)$ \\
$\Delta$ Turnover $^{\wedge}$ & 0.130 \\
& & $(0.083)$ \\
$\Delta$ Total assets^ $^{\wedge}$ & 0.183 \\
$\Delta$ Profits $^{\wedge}$ & & $(0.279)$ \\
& & -0.629 \\
$\Delta$ Employees $^{-1}$ & & $(2.465)$ \\
& & -7.535 \\
$\Delta$ Other capital income $^{\wedge}$ & & $(12.391)$ \\
& & -0.352 \\
& & $(0.228)$ \\
\hline Observations & 5,613 & 5,613 \\
R-squared & 0.348 & 0.349 \\
\hline standard errors in parentheses. ${ }^{* * *} \mathrm{p}<0.01$. &
\end{tabular}

Notes: Owner-level clustered robust standard errors in parentheses.*** $\mathrm{p}<0.01$.

- In 1,000 euros

Table 7: Results for the years 2002 and 2008 


\begin{tabular}{|c|c|c|c|c|c|c|}
\hline VARIABLES & $\begin{array}{c}\text { Turnover } \\
0-25 \text { th p } \\
\Delta \mathrm{W}\end{array}$ & $\begin{array}{c}\text { Turnover } \\
26-50 \text { th p } \\
\Delta \mathrm{W} \\
\end{array}$ & $\begin{array}{c}\text { Turnover } \\
51-75 \text { th p } \\
\Delta \mathrm{W}\end{array}$ & $\begin{array}{c}\text { Turnover } \\
76-100 \text { th p } \\
\Delta \mathrm{W} \\
\end{array}$ & $\begin{array}{c}\text { Employees } \\
0-25 \mathrm{th} \mathrm{p} \\
\Delta \mathrm{W} \\
\end{array}$ & $\begin{array}{c}\text { Employees } \\
26-50 \text { th p } \\
\Delta \mathrm{W} \\
\end{array}$ \\
\hline$\triangle W^{*}$ & $\begin{array}{c}0.676 * * * \\
(0.028)\end{array}$ & $\begin{array}{c}0.597 * * * \\
(0.029)\end{array}$ & $\begin{array}{c}0.646 * * * \\
(0.028)\end{array}$ & $\begin{array}{c}0.613 * * * \\
(0.033)\end{array}$ & $\begin{array}{c}0.604 * * * \\
(0.025)\end{array}$ & $\begin{array}{c}0.626 * * * \\
(0.034)\end{array}$ \\
\hline $\begin{array}{l}\text { Observations } \\
\text { R-squared }\end{array}$ & $\begin{array}{l}1,528 \\
0.383\end{array}$ & $\begin{array}{l}1,529 \\
0.345\end{array}$ & $\begin{array}{l}1,529 \\
0.365 \\
\end{array}$ & $\begin{array}{l}1,529 \\
0.253 \\
\end{array}$ & $\begin{array}{l}2,009 \\
0.317 \\
\end{array}$ & $\begin{array}{l}1,387 \\
0.332\end{array}$ \\
\hline VARIABLES & $\begin{array}{c}\text { Employees } \\
51-75 \text { th p } \\
\Delta \mathrm{W} \\
\end{array}$ & $\begin{array}{c}\text { Employees } \\
76-100 \text { th p } \\
\Delta \mathrm{W} \\
\end{array}$ & $\begin{array}{c}\text { Total assets } \\
0-25 \text { th p } \\
\Delta \mathrm{W}\end{array}$ & $\begin{array}{c}\text { Total assets } \\
26-50 \text { th p } \\
\Delta \mathrm{W}\end{array}$ & $\begin{array}{c}\text { Total assets } \\
51-75 \text { th p } \\
\Delta \mathrm{W}\end{array}$ & $\begin{array}{c}\text { Total assets } \\
76-100 \text { th p } \\
\Delta \mathrm{W} \\
\end{array}$ \\
\hline$\Delta W^{*}$ & $\begin{array}{c}0.606 * * * \\
(0.027)\end{array}$ & $\begin{array}{c}0.655 * * * \\
(0.033)\end{array}$ & $\begin{array}{c}0.738 * * * \\
(0.027)\end{array}$ & $\begin{array}{c}0.711 * * * \\
(0.024)\end{array}$ & $\begin{array}{c}0.640 * * * \\
(0.024)\end{array}$ & $\begin{array}{c}0.647 * * * \\
(0.033)\end{array}$ \\
\hline $\begin{array}{l}\text { Observations } \\
\text { R-squared }\end{array}$ & $\begin{array}{l}1,301 \\
0.377 \\
\end{array}$ & $\begin{array}{l}1,418 \\
0.302 \\
\end{array}$ & $\begin{array}{l}1,529 \\
0.359 \\
\end{array}$ & $\begin{array}{l}1,529 \\
0.417 \\
\end{array}$ & $\begin{array}{l}1,529 \\
0.380 \\
\end{array}$ & $\begin{array}{l}1,528 \\
0.262 \\
\end{array}$ \\
\hline VARIABLES & $\begin{array}{c}\text { Age } \\
0-25 \text { th p } \\
\Delta \mathrm{W}\end{array}$ & $\begin{array}{c}\text { Age } \\
26-50 \text { th p } \\
\Delta \mathrm{W}\end{array}$ & $\begin{array}{c}\text { Age } \\
51-75 \text { th p } \\
\Delta \mathrm{W}\end{array}$ & $\begin{array}{c}\text { Age } \\
76-100 \text { th p } \\
\Delta \mathrm{W}\end{array}$ & Male & Female \\
\hline$\triangle W^{*}$ & $\begin{array}{c}0.601 * * * \\
(0.028)\end{array}$ & $\begin{array}{c}0.628 * * * \\
(0.028)\end{array}$ & $\begin{array}{c}0.606 * * * \\
(0.032)\end{array}$ & $\begin{array}{c}0.583 * * * \\
(0.037)\end{array}$ & $\begin{array}{c}0.623 * * * \\
(0.017)\end{array}$ & $\begin{array}{c}0.590 * * * \\
(0.033)\end{array}$ \\
\hline $\begin{array}{l}\text { Observations } \\
\text { R-squared }\end{array}$ & $\begin{array}{l}1,597 \\
0.330\end{array}$ & $\begin{array}{l}1,587 \\
0.348\end{array}$ & $\begin{array}{l}1,623 \\
0.283\end{array}$ & $\begin{array}{l}1,308 \\
0.274\end{array}$ & $\begin{array}{l}5,247 \\
0.318\end{array}$ & $\begin{array}{c}868 \\
0.355\end{array}$ \\
\hline VARIABLES & $\begin{array}{c}\text { Agriculture } \\
\Delta \mathrm{W} \\
\end{array}$ & $\begin{array}{c}\text { Mining } \\
\Delta \mathrm{W} \\
\end{array}$ & $\begin{array}{c}\text { Industry } \\
\Delta \mathrm{W}\end{array}$ & $\begin{array}{c}\text { Construction } \\
\Delta \mathrm{W} \\
\end{array}$ & $\begin{array}{c}\text { Commerce } \\
\Delta \mathrm{W}\end{array}$ & $\begin{array}{c}\text { Hotels } \\
\Delta \mathrm{W} \\
\end{array}$ \\
\hline$\triangle W^{*}$ & $\begin{array}{c}0.836 * * * \\
(0.108) \\
\end{array}$ & $\begin{array}{c}0.561 * * * \\
(0.081) \\
\end{array}$ & $\begin{array}{c}0.692 * * * \\
(0.048) \\
\end{array}$ & $\begin{array}{c}0.570 * * * \\
(0.035) \\
\end{array}$ & $\begin{array}{c}0.600 * * * \\
(0.030)\end{array}$ & $\begin{array}{c}0.638 * * * \\
(0.092) \\
\end{array}$ \\
\hline $\begin{array}{l}\text { Observations } \\
\text { R-squared }\end{array}$ & $\begin{array}{c}70 \\
0.537 \\
\end{array}$ & $\begin{array}{c}156 \\
0.394 \\
\end{array}$ & $\begin{array}{c}842 \\
0.335 \\
\end{array}$ & $\begin{array}{l}1,070 \\
0.308 \\
\end{array}$ & $\begin{array}{l}1,500 \\
0.322 \\
\end{array}$ & $\begin{array}{c}137 \\
0.430 \\
\end{array}$ \\
\hline & Logistics & Finance & Estate & Education & Health care & $\begin{array}{c}\text { Other } \\
\text { services }\end{array}$ \\
\hline VARIABLES & $\Delta \mathrm{W}$ & $\Delta \mathrm{W}$ & $\Delta \mathrm{W}$ & $\Delta \mathrm{W}$ & $\Delta \mathrm{W}$ & $\Delta \mathrm{W}$ \\
\hline$\triangle W^{*}$ & $\begin{array}{c}0.563 * * * \\
(0.078)\end{array}$ & $\begin{array}{c}0.964 * * * \\
(0.107)\end{array}$ & $\begin{array}{c}0.636 * * * \\
(0.028)\end{array}$ & $\begin{array}{c}0.693 * * * \\
(0.124)\end{array}$ & $\begin{array}{c}0.658 * * * \\
(0.068)\end{array}$ & $\begin{array}{c}0.579 * * * \\
(0.108)\end{array}$ \\
\hline Observations & 462 & 63 & 1,433 & 48 & 208 & 125 \\
\hline R-squared & 0.254 & 0.660 & 0.342 & 0.590 & 0.423 & 0.346 \\
\hline
\end{tabular}

Note: Owner-level clustered robust standard errors in parentheses.*** $\mathrm{p}<0.01$.

Table 8: Results for different subgroups, 2002-2008 